MENS \& MAATSCHAPPIJ

www.mensenmaatschappij.nl

Uitgave: Amsterdam University Press

\title{
Sprekende voorbeelden
}

De positieve invloed van instructiefilmpjes op natuurkundetoetsen in de bovenbouw van het vwo

Manfred te Grotenhuis, Amber Walraven \& Nico van de Mortel

MEM 91 (1): 77-92

DOI: 10.5117/MEM2016.1.GROT

\begin{abstract}
Summary
Living examples: the positive effect of instructional videos on physics tests in Dutch pre-university classes

Aim of this study is to measure the effect of instructional videos on physics tests, taken in the highest classes of Dutch pre-university education (vwo 5 and 6) in 2014. The students (aged between 17 and 19) were randomly assigned to experimental and control groups. In a first trial, the control group used a textbook to prepare for a physics test, while the experimental group watched instructional videos on YouTube. In a second trial, the control group watched the videos and the experimental group used the textbook to prepare for a second physics test. In this research design, both between and within group comparisons of the test results have been made. Each and every comparison indicated a significant and relevant positive effect: if instead of a textbook, videos were used for preparation, the percentage of correct answers improved with 10.5 points $[90 \% \mathrm{Cl} 7.5-13.5]$ and the average percentile score increased with 24 points [ $90 \% \mathrm{Cl} 17-30$ ], with an overall effect size (Cohen's D) of 0.9. This indicates a strong positive influence on tests results when short instructional videos are being used in class.
\end{abstract}

Keywords: instructional videos, YouTube, experiment, physics test

\section{$1 \quad$ Inleiding}

Sinds enige tijd is er een verschuiving merkbaar van traditionele leerboeken naar digitale leermiddelen in het voortgezet onderwijs. Niet alleen 
worden de leerboeken zelf gedigitaliseerd aangeboden, vaak met verwijzingen naar internetpagina's, maar er is ook een sterke toename van het aanbod aan videolessen via het internet. Zo bieden enige universiteiten in Nederland de colleges aan via een eigen videokanaal. Ook gerenommeerde buitenlandse universiteiten zoals Princeton bieden (tegen betaling) opgenomen colleges aan. Recentelijk (2012) ging Cousera van start, een internetorganisatie met een grote verzameling opgenomen colleges van topuniversiteiten, die gratis beschikbaar wordt gesteld. Op hbo- en vwo-niveau is er eerder sprake van particuliere initiatieven die doorgaans op YouTube zijn te vinden, vanwege de eenvoud van het beschikbaar stellen. Vaak zijn het gratis instructielessen, ingesproken door docenten, maar er zijn ook professionele bedrijven die tegen betaling (korte) video's aanbieden.

Binnen het onderwijs heeft het gebruik van videobeelden altijd al in de belangstelling gestaan, maar sinds de komst van YouTube heeft het een hoge vlucht genomen. Leerlingen maken inmiddels massaal gebruik van de talrijke instructiefilmpjes tijdens de voorbereiding op toetsen en eindexamens. Uit de monitor Jeugd en Media (een enquête onder 1741 leerlingen tussen de 12 en 18 jaar) blijkt dat 26 procent van de jongeren uitleg zoekt over de lesstof via YouTube. Leerlingen geven ook aan dat YouTube hen heeft geholpen, bijvoorbeeld met het oplossen van een wiskundeprobleem (Kennisnet, 2015). Rondom de eindexamens in 2015 kwam Kennisnet met een 'YouTube-docenten top 16', presenteerde Scholieren.com een verzameling van de beste eindexamen-video's, hield de Volkskrant een hele serie interviews met verschillende YouTube-docenten en schoof een aantal docenten aan bij 'De Wereld Draait Door'. Hoewel het veelvuldig gebruik van YouTube door leerlingen doet vermoeden dat dit bijdraagt aan een betere voorbereiding op toetsen en examens, is het nog niet in een experiment vastgesteld. Onze vraagstelling luidt dan ook: in hoeverre is er een positief effect van korte instructiefilmpjes op toetsresultaten? We beantwoorden deze vraag door een experimentele opzet te kiezen en verschillen in resultaten te meten tussen gerandomiseerde groepen vwo-leerlingen die zich met en zonder instructiefilm voorbereiden op een toets.

\section{Theoretisch kader en hypothese}

Het uitgebreide literatuuroverzicht van Kay (2012) laat zien dat leerlingen videomateriaal gebruiken om betere leerresultaten te behalen. Ze bekijken filmpjes ter voorbereiding op lessen en examens, om te testen of ze de lesstof begrijpen, of om al een eerste beeld te krijgen van de te behandelen 
onderwerpen. Daarnaast geeft dit leerlingen een gevoel van controle over het wanneer, waar, wat en over het tempo van het leren. De meeste leerlingen staan positief tegenover dergelijke filmpjes, vinden ze motiverend, bruikbaar en effectief voor het leerproces (Crippen \& Earl, 2004; Dupagne, Millette, \& Grinfeder, 2009; Traphagan, Kusera, \& Kishi, 2010). Onderzoek bevestigt de positieve gevoelens van leerlingen over het gebruik: leerlingen die video gebruiken behalen significant hogere toetsresultaten dan leerlingen die deelnemen aan meer traditioneel onderwijs (Boster, Meyer, Roberto, Inge, \& Strom, 2006; Crippen, \& Earl, 2004). De genoemde studies hebben echter een beperking. Tussen de condities worden vaak meer verschillen gemaakt dan alleen het gebruik van video's; soms bevat de conditie met videomateriaal meer activerende werkvormen en kenmerkt de conditie zonder video zich door meer docentgestuurd, weinig interactief onderwijs (McLaughlin e.a., 2014). Eventuele verschillen in toetsresultaten tussen condities zijn dan mogelijk niet alleen toe te schrijven aan het gebruik van videobeelden, maar ook aan het gebruik van actieve werkvormen. Dat deze actieve werkvormen van belang zijn, wordt ook duidelijk in onderzoek naar het populaire flipping the classroom. Bij deze methode wordt de lesstof voorafgaand aan de klassikale bijeenkomst via video verspreid. De contacttijd wordt vervolgens besteed aan het verwerken van de informatie door middel van verdiepingsopdrachten (Bergmann \& Sams, 2009). Een docent kan daardoor meer directe feedback en assistentie geven en is minder tijd kwijt aan de instructies (Warter-Perez \& Dong, 2012). Het online aanbieden van deze video's betekent dat leerlingen onafhankelijk van tijd en plaats de theorie en kennis tot zich kunnen nemen en controle hebben over het tempo en de frequentie van kennisoverdracht. Veel van de onderzoeken over flipping the classroom gaan echter over percepties van studenten en maken in het onderzoek geen gebruik van een controlegroep. Het gaat veelal om anekdotisch bewijs en er is weinig onderzoek naar objectieve leerresultaten. Uit bovenstaande kunnen we een aantal zaken concluderen:

- Leerlingen gebruiken veelvuldig videomateriaal bij het voorbereiden op een toets, veelal via YouTube. Dit doen ze vaak uit zichzelf, onafhankelijk van de docent en onafhankelijk van het type les dat ze krijgen.

- Onderzoek naar het gebruik van video's in het onderwijs is vaak gebaseerd op behoorlijke verschillen in condities naast het gebruik van video's.

- Onderzoek naar flipping the classroom waarin video's een prominente rol vervullen, is veelal gebaseerd op percepties en niet op objectieve gegevens en maakt geen gebruik van een controlegroep. 
Vanwege de populariteit van video's onder leerlingen / studenten en de onbekendheid met het veronderstelde leereffect, wordt hier nagegaan wat het effect is van het bekijken van korte filmpjes over natuurkunde op de leerprestaties van 17 tot 19-jarige vwo-leerlingen uit klas 5 en 6. Op deze manier kunnen we aansluiten bij wat jongeren uit zichzelf al veel doen, hoeven we geen aanpassingen aan te brengen in de didactiek, verzamelen we objectieve gegevens en kunnen we beter de verschillen ten gevolge van het videogebruik isoleren. Aangezien het gebruik van visuele stimuli (waaronder video en multimedia presentaties) de betrokkenheid van leerlingen verhoogt (Renshaw \& Taylor, 2000) en hogere betrokkenheid in relatie staat met leerresultaat (Marks, 2000), is het aannemelijk dat het gebruik van video's een positief effect heeft op leren. Daarbij stelt het modaliteitsprincipe dat men nieuwe stof beter onthoudt (kennis) en kan toepassen in breder verband en in nieuwe situaties (inzicht of 'transfer') als de combinatie visueel / auditief wordt gebruikt. Leerlingen leren beter als de lesstof naast grafische voorstellingen ook gesproken tekst bevat in plaats van geschreven tekst (Mayer, 2009). Het principe is vooral getoetst in experimenteel onderzoek waarin volwassenen op basis van toeval werden ingedeeld in een groep waarin men geschreven teksten en afbeeldingen te zien kreeg, of in een groep waarin men afbeeldingen te zien kreeg in combinatie met dezelfde tekst, maar nu uitgesproken. Hieruit bleek dat de tweede groep doorgaans (veel) beter scoorde op een toets over de gepresenteerde lesstof. Voor een overzicht van relevante studies en de uitkomsten van een meta-analyse verwijzen we naar een studie van Ginns (2005). Uit de uitgevoerde meta-analyse (43 studies) kwam in het algemeen een (vrij) sterk effect naar voren $(d=0,72 ; 95 \% \mathrm{BI}=0,52-0,92)$. Het effect was afhankelijk van moeilijkheidsgraad (hoe moeilijker de lesstof, des te groter het effect) en voorbereidingstijd (als de student in eigen tempo mocht werken nam het effect af). Harskamp, Mayer en Suhre (2007) vonden voor Nederland ook een relatief sterk effect van de combinatie beeld / geluid ten opzichte van beeld / geschreven tekst op de uitslag van een biologietoets, vooral als het ging om inzicht. Het vergelijken van leerlingen die afbeeldingen en tekst zien met leerlingen die dezelfde afbeeldingen en tekst zien, maar de tekst ook horen, is uitstekend voor een zuivere vergelijking, maar doet geen recht aan de praktijk. De veelbekeken instructiefilmpjes worden vaak gemaakt op basis van bestaande leerboeken. Qua inhoud zijn deze filmpjes gelijk aan de leerboeken, maar de afbeeldingen zijn vaak dynamischer, terwijl de tekst vaak samenvattend of kernachtig wordt gebracht. Omdat de lesstof in de leerboeken niet exact gelijk is aan die in de filmpjes, kunnen we dus niet zonder meer stellen dat vanwege het 
modaliteitsprincipe het bekijken van de instructiefilmpjes tot een beter resultaat leidt. In ieder geval doen alle hier genoemde studies, hoe gevarieerd ook, vermoeden dat de filmpjes tot een beter leerresultaat leiden, ook omdat het bekijken van filmpjes op YouTube gemeengoed onder jongeren geworden is en past bij de huidige beeldcultuur, waarin jongeren minder lezen en meer gebruik maken van het internet. Concreet toetsen we de volgende hypothese: het voorbereiden op een meerkeuzetoets vwo-natuurkunde met behulp van korte instructiefilmpjes leidt tot betere resultaten dan het voorbereiden met behulp van een boek.

\section{Gegevens en onderzoeksmethode}

Vwo-leerlingen uit klas 5 en klas 6 (studiejaar 2014-2015) zijn op basis van toeval ingedeeld in vier groepen. In klas 5 zijn de groepen 1 (bestaande uit 11 leerlingen) en 2 (14 leerlingen) gevormd en in klas 6 groep 3 (17 leerlingen) en groep 4 (16 leerlingen). Voorafgaand aan de eerste toets kregen alle leerlingen uit klas 5 klassikaal les over de paragrafen 1 (horizontale worp), 2 (cirkels, graden, radialen) en 3 (eenparige cirkelbeweging) uit het hoofdstuk 'Kromlijnige bewegingen' van het leerboek Systematische Natuurkunde vwo 5 (Van Eekelen \& De Jong, 2007). Alle leerlingen uit klas 6 kregen eerst klassikaal les over de onderwerpen straling, atoomkernen, vervalvergelijkingen en halveringstijd (Van Eekelen \& De Jong, 2009). Een week later lazen de leerlingen uit groep 1 (klas 5 ) en groep 3 (klas 6) zelfstandig de genoemde paragrafen. De leerlingen uit groep 2 (klas 5 ) en groep 4 (klas 6) kregen over elke paragraaf een filmpje te zien via natuurkundeuitgelegd.nl en mochten hun boek niet meer gebruiken. De leestijd en de kijktijd (ongeveer 30 minuten) zijn in het experiment gelijk gehouden; de leestijd was ruim voldoende om de lesstof te bestuderen (uitgaande van 175 woorden per minuut). Direct hierna werden meerkeuzetoetsen afgenomen in klas 5 (12 vragen) en 6 (18 vragen) over de behandelde lesstof. Bij de toetsen mocht gebruik worden gemaakt van een naslagwerk (BINAS) en een rekenmachine. ${ }^{1}$ Een week na de eerste toets kregen alle leerlingen uit klas 5 klassikaal les over middelpuntzoekende kracht en gravitatiekracht, terwijl klas 6 les kreeg over ioniserende straling, detectie van straling en effecten van straling. In de daaropvolgende week waren de rollen omgedraaid en kregen de leerlingen uit groep 2 en 4 de leestijd en bekeken de leerlingen uit groep 1 en 3 de filmpjes (ook hier zijn lees- en kijktijd gelijk). Direct daarna volgden weer meerkeuzetoetsen (12 
vragen per toets). Het experiment betreft dus het vaststellen van een eventueel leereffect op de korte termijn.

Door deze opzet is het mogelijk om de uitslagen van een toets tussen twee groepen te vergelijken, maar kunnen ook de uitslagen van de twee toetsen binnen een groep vergeleken worden. Dit leverde in totaal acht vergelijkingen op tussen leerlingen die het boek lazen en leerlingen die de filmpjes bekeken. In figuur 1 is de onderzoeksopzet schematisch weergegeven.

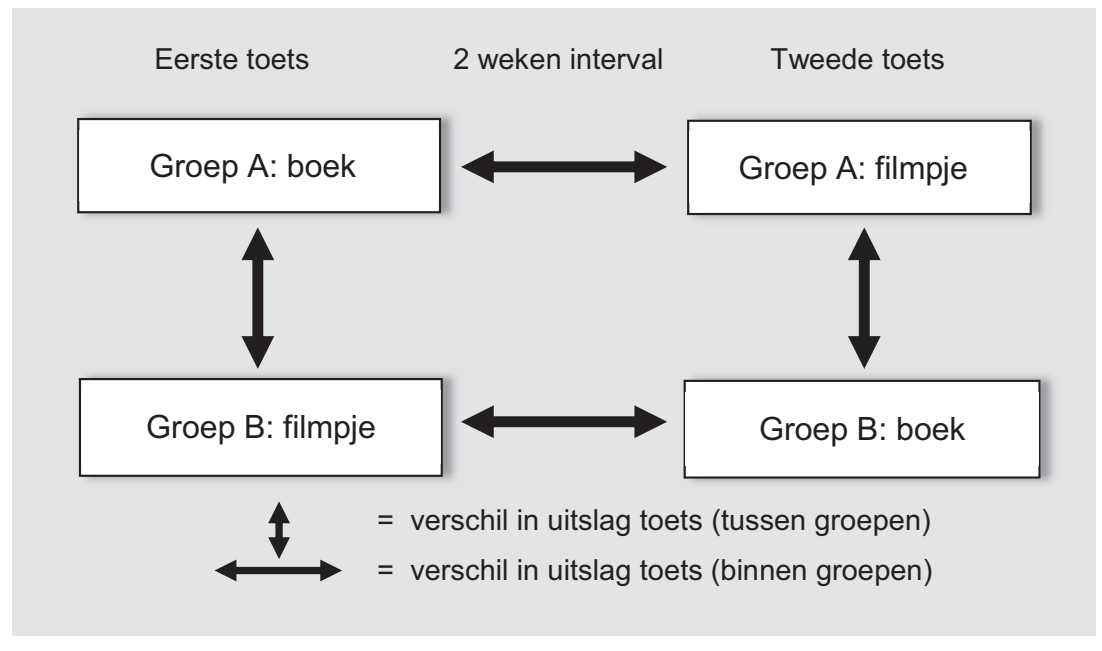

Figuur 1 Het onderzoeksontwerp. De leerlingen uit een klas zijn op basis van toeval ingedeeld in 2 groepen ( $A=b o e k, B=f i l m p j e)$ en daarna is een toets afgenomen. Vervolgens zijn de groepen omgedraaid ( $A=f i l m p j e, B=b o e k)$ en is een tweede toets afgenomen. Hierdoor zijn vergelijkingen mogelijk tussen de groepen en binnen elke groep.

Om te toetsen of de groepsverschillen statistisch significant zijn, is vanwege het relatief kleine aantal leerlingen per groep gebruik gemaakt van bootstrapping (Fox, 2002). ${ }^{2}$ Voor de vergelijking van één toets tussen twee groepen wordt gekeken naar verschillen in het percentage goede antwoorden. Omdat de meerkeuzetoetsen in onderwerp en moeilijkheidsgraad verschillend zijn, werden de resultaten eerst gestandaardiseerd door voor elke leerling de percentielscore te berekenen. Deze score geeft voor elke leerling aan hoeveel procent van de leerlingen net zo goed, of minder goed scoorde op de toets. Een verdere uitleg wordt in de volgende paragraaf gegeven. 


\section{$4 \quad$ Analyses}

\subsection{Verschillen tussen de groepen}

Om de verschillen tussen de groepen te meten, is per toets het gemiddelde percentage goede antwoorden uitgerekend in elke groep. De vijfde-klasleerlingen uit groep 1 (boek) hadden bij de eerste toets gemiddeld 72,7 procent van de antwoorden goed, in groep 2 (filmpjes) was dat 84,5 procent (zie tabel 1). Het verschil (11,8 procentpunten) is statistisch significant ( $\alpha=0,05$ enkelzijdig). De 90\%-betrouwbaarheidsinterval (BI) rond dit verschil is 3,0-20,7. Dit betekent dat vermoedelijk het verschil in de populatie ergens ligt tussen deze twee waarden. Twee weken later scoorden juist de leerlingen uit groep 1 (dit keer filmpjes ter voorbereiding) gemiddeld beter dan groep 2 (boekvoorbereiding): 68,9 procent goede antwoorden tegen 57,7 procent. Ook hier is het verschil $(11,0)$ statistisch significant $(\alpha=0,05$ enkelzijdig; $90 \% \mathrm{BI}=0,4-21,7$ ). Merk op dat de tweede toets door de leerlingen uit klas 5 gemiddeld minder goed is gemaakt dan de eerste. Dit duidt erop dat de behandelde thema's uit het tweede deel moeilijker zijn geweest. Voor de groepen 3 en 4 uit de zesde klas is het beeld vrijwel identiek: als leerlingen de filmpjes bekeken, had men gemiddeld een hoger percentage antwoorden goed dan wanneer men het boek las. Daarbij

Tabel 1 De verschillen tussen de groepen uitgedrukt in het gemiddelde percentage goede antwoorden

\begin{tabular}{|c|c|c|c|}
\hline & $\begin{array}{l}\text { Gemiddeld percentage } \\
\text { goede antwoorden }\end{array}$ & Verschil in gemiddelde & $\begin{array}{l}90 \% \text { betrouwbaar- } \\
\text { heidsinterval* }\end{array}$ \\
\hline vwo 5 & & \multirow{5}{*}{11,8} & \multirow{5}{*}{$3,0-20,7$} \\
\hline Toets 1 & & & \\
\hline Groep 1: boek ( $n=11)$ & 72,7 & & \\
\hline Groep 2: filmpje $(n=14)$ & 84,5 & & \\
\hline Toets 2 & & & \\
\hline Groep 2: boek $(n=14)$ & 57,7 & \multirow[t]{4}{*}{11,2} & \multirow[t]{4}{*}{$0,4-21,7$} \\
\hline Groep 1: filmpje $(n=11)$ & 68,9 & & \\
\hline vwo 6 & & & \\
\hline Toets 3 & & & \\
\hline Groep 3: boek ( $n=17$ ) & 75,4 & \multirow[t]{3}{*}{10,7} & \multirow[t]{3}{*}{$5,3-16,1$} \\
\hline Groep 4: filmpje ( $n=16)$ & 86,1 & & \\
\hline Toets 4 & & & \\
\hline Groep 4: boek ( $n=16)$ & 82,8 & \multirow[t]{2}{*}{8,4} & \multirow[t]{2}{*}{$3,3-13,4$} \\
\hline Groep 3: filmpje $(n=17)$ & 91,2 & & \\
\hline
\end{tabular}

* Zie eindnoot 2 voor details over de bepaling van de $90 \%$ betrouwbaarheidsintervallen. 
de opmerking dat het effect in toets $4(8,4)$ het laagst is. Dit is niet verwonderlijk aangezien deze toets zeer goed gemaakt is, waardoor gemakkelijk plafondeffecten ontstaan: men kan immers niet meer dan 100 procent goed hebben. Daardoor hebben absolute verschillen de natuurlijke neiging om kleiner te worden naarmate het percentage goede antwoorden dichter bij 100 procent ligt. Het gemiddelde effect over de vier vergelijkingen is 10,5 procentpunten $[90 \% \mathrm{BI}=7,5-13,5]$. In tabel 1 zijn de belangrijkste uitkomsten samengevat.

\subsection{Verschillen binnen de groepen}

Bij de vergelijkingen tussen de groepen moest worden aangenomen dat de verschillen niet het gevolg zijn van andere relevante groepsverschillen die ondanks de toevalstoewijzing wellicht toch zijn blijven bestaan. Een andere manier om het effect van de filmpjes te meten, is een vergelijking binnen elke groep. Zo kan voor de leerlingen uit de eerste groep de uitslag van de eerste toets worden vergeleken met die van de tweede toets. Als we beide toetsen in groep 1 vergelijken, dan is de eerste toets $(72,7$ procent goede antwoorden met boekvoorbereiding) beter gemaakt dan de tweede toets $(68,9$ procent, video); zie tabel 1 . Daarmee lijkt het lezen van het boek een betere voorbereiding op de toets dan het kijken naar de filmpjes. De vergelijking is echter oneerlijk omdat de toetsen gaan over verschillende onderwerpen en ook in moeilijkheidsgraad verschillen. Om een juiste vergelijking te maken, is het noodzakelijk om de toetsresultaten te standaardiseren. We hebben hier gekozen voor percentielscores, die de relatieve positie van een leerling ten opzichte van alle andere leerlingen laat zien. Een lage percentielscore, bijvoorbeeld 10, geeft aan dat 10 procent van alle leerlingen hetzelfde of nog lager scoorde op de toets dan deze leerling. Dat is een relatief slecht resultaat, immers go procent van alle leerlingen haalde een hoger cijfer dan de leerling met percentielscore 10. Het gaat ons bij de groepsvergelijkingen niet om de individuele uitslagen, maar om de prestatie van een groep als geheel. Daarom is de gemiddelde percentielscore per groep uitgerekend. ${ }^{3}$ Hoe hoger de gemiddelde percentielscore, des te beter is het tentamen binnen de groep gemaakt. Voor de leerlingen uit groep 1 die zich op de eerste toets hebben voorbereid met het leerboek, was de gemiddelde percentielscore 47,4. Bij de tweede toets, dus na het volgen van de filmpjes, was de gemiddelde percentielscore in deze groep gestegen tot 69,6 . Dit betekent dat in groep 1 de tweede toets relatief gezien beter werd gemaakt dan de eerste toets. De verschuiving in de gemiddelde percentielscore is sterk (22,2 punten) en statistisch significant (de 90\%-betrouw- 
baarheidsinterval bedraagt 9,8 - 33,8). Dit geldt ook voor de vergelijking binnen groep 2 van klas 5 en voor de vergelijkingen binnen groep 3 en 4 van klas 6: de toets wordt aanmerkelijk beter gemaakt als de filmpjes worden bekeken in vergelijking tot het bestuderen van het leerboek. De resultaten zijn in tabel 2 samengevat. ${ }^{4}$

Tabel 2 De verschillen binnen de groepen uitgedrukt in de gemiddelde percentielscores

\begin{tabular}{|c|c|c|c|}
\hline & $\begin{array}{c}\text { Gemiddelde } \\
\text { percentielscore }\end{array}$ & Verschil in gemiddelde & $\begin{array}{l}\text { 90\% betrouwbaar- } \\
\text { heidsinterval* }\end{array}$ \\
\hline \multicolumn{4}{|l|}{ vwo 5} \\
\hline Toets 1 & & & \\
\hline Groep 1: boek ( $n=11$ ) & 47,4 & 22,2 & $9,8-33,8$ \\
\hline Groep 1: filmpje ( $n=11)$ & 69,6 & & \\
\hline \multicolumn{4}{|l|}{ Toets 2} \\
\hline Groep 2: boek ( $n=14)$ & 52,1 & 20,0 & $10,3-29,7$ \\
\hline Groep 2: filmpje $(n=14)$ & 72,1 & & \\
\hline \multicolumn{4}{|l|}{ vwo 6} \\
\hline \multicolumn{4}{|l|}{ Toets 3} \\
\hline Groep 3: boek ( $n=17)$ & 44,8 & 30,2 & $21,6-38,5$ \\
\hline Groep 3: filmpje $(n=17)$ & 75,0 & & \\
\hline \multicolumn{4}{|l|}{ Toets 4} \\
\hline Groep 4: boek ( $n=16$ ) & 50,2 & 23,0 & $13,1-32,2$ \\
\hline Groep 4: filmpje $(n=16)$ & 73,2 & & \\
\hline
\end{tabular}

Uit tabel 2 blijkt dat de verschuiving in percentielscore per groep respectievelijk 22,2 (groep 1); 20,0 (2); 30,2 (3) en 23,0 (4) bedraagt. Gemiddeld genomen is dat ongeveer 24 punten [ $90 \% \mathrm{BI} 17-30]$. Het is mogelijk dat de verschuiving binnen elke groep een toevalsafwijking is van dit gemiddelde. Dit zou betekenen dat het voor het effect niet uitmaakt of de leerling filmpjes bekeek voor toets 1 en vervolgens het boek las als voorbereiding op de tweede toets of andersom (eerst boek, dan filmpje) en dat het ook irrelevant in welke klas de leerling zit. Dit is uitgezocht door een lineaire regressieanalyse uit te voeren met het verschil in percentielscore als afhankelijke variabele, en de volgorde van voorbereiding, de klas en de interactie tussen klas en volgorde als voorspellers van het verschil. De klas en de volgorde (en de combinatie klas-volgorde) bleken geen significante voorspellers te zijn (zie de tabellen A en B in de appendix voor details). Omdat het leer- 
effect blijkbaar onafhankelijk is van de groep waartoe de leerling behoorde, is voor elke leerling de percentielscore die is behaald met het leerboek als voorbereiding afgezet tegen de percentielscore die is behaald met het kijken van filmpjes (zie figuur 2). In de figuur wordt dus geen onderscheid meer gemaakt naar volgorde en klas of de combinatie daarvan, aangezien het aannemelijk is dat deze factoren geen, of een geringe invloed hebben op het leereffect van filmpjes. In figuur 2 zijn over het algemeen de lijnen stijgend. Dit betekent dat de percentielscores doorgaans hoger zijn als filmpjes werden gevolgd in plaats van de boekvoorbereiding. Slechts bij acht leerlingen was het effect tegengesteld en bij vijf leerlingen was er geen enkel verschil waarneembaar. De figuur laat ook bodem- en plafond-

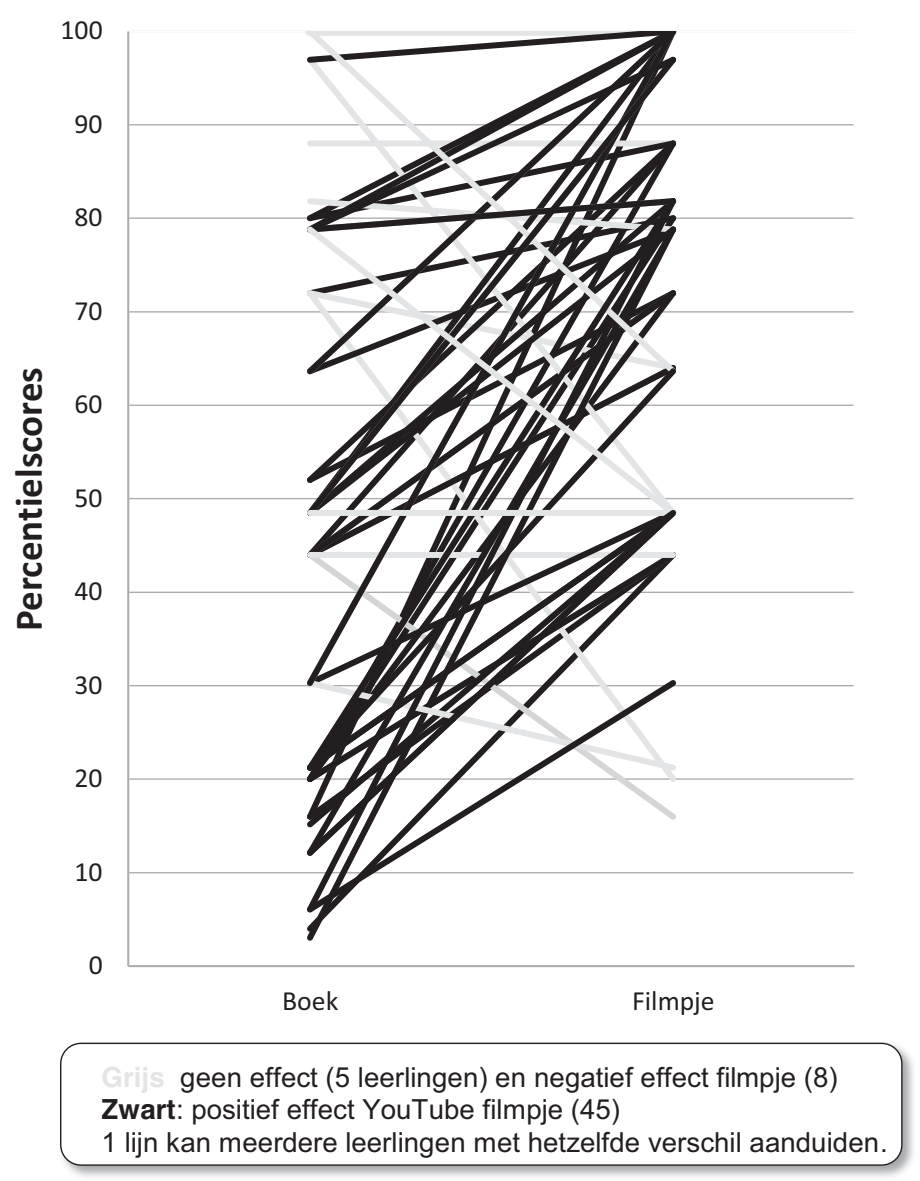

Figuur 2 De percentielscores voor leerlingen $(n=58)$ met het boek als voorbereiding (links) en de percentielscores voor dezelfde leerlingen met het filmpje als voorbereiding (rechts), gemiddelde effect is 24,3 percentielpunten 
effecten zien, ofwel regressie naar het gemiddelde: als een leerling erg hoog scoort bij de ene meting, dan is de kans groot dat deze bij de andere meting lager scoort. Omgekeerd geldt uiteraard ook dat zeer laag scorende leerlingen bij de ene toets een grote kans hebben om hoger te scoren bij de andere toets. De gemiddelde verschuiving in percentielscore ging voor alle 58 leerlingen samen van 47,2 (boek) naar 71,5 (video) en bedraagt daarmee 24,3 percentielpunten. Dit betekent dat een leerling die de instructiefilmpjes bekeek, gemiddeld genomen een cijfer behaalde dat door 28,5 procent van de leerlingen werd overtroffen (100-71,5), terwijl dezelfde leerling met de boekvoorbereiding ziet dat meer dan de helft van de andere leerlingen het beter doet (100-47,2). Dit mag gerust een substantieel verschil worden genoemd. Dit blijkt ook uit de berekening van Cohen's $D$, die aangeeft hoeveel de verschuiving $(=24,3)$ is, uitgedrukt in de standaardafwijking van de percentielscores $(=26,4)$ : deze is 0,9 (berekening: $24,3 / 26,4)$. Effectgroottes boven de 0,8 worden in de literatuur als 'sterk' betiteld.

\section{$5 \quad$ Conclusie en discussie}

In deze studie is onderzocht of korte instructiefilmpjes als aanvulling op klassikaal onderwijs tot betere toetsresultaten leiden dan het louter zelfstandig lezen van een leerboek. Uit de vergelijkingen tussen film- en boekvoorbereiding kwam eenduidig naar voren dat het bekijken van de instructiefilmpjes een sterk positief effect had op het behaalde toestsresultaat. De vergelijkingen tussen de groepen lieten zien dat het percentage goede antwoorden met gemiddeld 10,5 punten $(90 \% \mathrm{BI}=7,5-13,5)$ steeg als de video's werden bekeken als voorbereiding in plaats van het lezen van het leerboek. De vergelijkingen binnen de groepen lieten een zelfde beeld zien: gemiddeld verschoof de relatieve positie in de verdeling van cijfers (uitgedrukt in een percentielscore) met 24 procentpunten $(90 \% \mathrm{BI}=17-30)$ in het voordeel van de instructiefilmpjes. Deze studie geeft daarmee een duidelijke aanwijzing dat de manier waarop leerlingen nu veelvuldig gebruik maken van filmpjes positief uitwerkt op hun resultaten. Er zijn echter wel een paar kanttekeningen te maken.

De kenmerken van het filmpje zijn in dit onderzoek niet meegenomen. Er is gebruik gemaakt van een filmpje waarbij de docent in beeld is, terwijl achter hem allerlei formules en animaties verschijnen. Onderzoek laat zien dat bij filmpjes waarin zowel de docent in beeld is als een opdracht (zoals het testen van een elektronische schakeling), de aandacht van de kijker wordt gestuurd, met een licht positief effect op het uitvoeren van de op- 
dracht (Van Gog, Verveer \& Verveer, 2014). Het is de moeite waard om te kijken of filmpjes waarbij de docent niet in beeld is, een vergelijkbaar effect opleveren.

Een aanzienlijke zwakte in ons onderzoek is dat de toetsen gemaakt zijn door de docent die ook de filmpjes heeft gemaakt. De toetsen zijn weliswaar geënt op het leerboek (net als de filmpjes), maar de kans bestaat dat de docent, al dan niet bewust, in de filmpjes aspecten uit de toets sterker heeft belicht dan de schrijvers van het leerboek. Een vervolgonderzoek zou gebruik kunnen maken van bijvoorbeeld een onafhankelijke, methode-gebonden toets, of een toets gemaakt door een docent die niet betrokken is bij de lessen, het boek en de filmpjes.

Verder is er de rol van de docent: de één brengt een bepaalde leerinhoud nu eenmaal beter over het voetlicht dan de ander. Het kan zijn dat de leerlingen hun eigen docent minder goed hebben begrepen, en dat het filmpje een andere (voor de leerlingen duidelijkere) uitleg bood. Wij hebben de didactische kwaliteiten van de docenten en de leesbaarheid van het boek in deze studie niet in kaart gebracht. De sterkte van het effect hangt daarom mede af van mogelijke verschillen in uitleg door de docent, in het boek en in het filmpje. Een volgend onderzoek zou hier licht op kunnen werpen.

Daarnaast kan het zijn dat leerlingen met meer aandacht en enthousiasme naar de filmpjes hebben gekeken en minder geconcentreerd waren tijdens het lezen. De verklaring ligt dan niet zozeer in de instructiefilmpjes als zodanig, maar in de populariteit van de beeldcultuur versus de leescultuur. Uit een enquête gehouden onder leerlingen na afloop van het experiment, bleek dat veel leerlingen (8o procent) het lastig vinden om de motivatie en concentratie te vinden om teksten te lezen, terwijl dat bij de filmpjes juist omgekeerd is. Op de vraag welke voorbereiding de beste was, koos 87 procent voor de filmpjes. Veel leerlingen (9o procent) vinden verder dat filmpjes niet alleen handig zijn voor moeilijke lesstof. Het kan dus zo zijn dat leerlingen al minder gewend zijn aan het lezen van boeken en dat zij daarom minder goed scoren op de toets als een boek als voorbereiding wordt gebruikt. Vervolgonderzoek zou de manier waarop leerlingen normaal gesproken hun toets voorbereiden in kaart kunnen brengen. Daarbij is het ook aan te raden om leerlingen tijdens het experiment te observeren, of na afloop korte interviews te houden om meer zicht te krijgen op hun concentratie bij de voorbereiding en hoe zij te werk gaan. Het is namelijk denkbaar dat wanneer leerlingen vaker filmpjes kijken en dit niet meer nieuw voor ze is, de concentratie of motivatie afneemt. Het kijken van een filmpje is dan 'gewoon' geworden. Het zogenaamde medi- 
um-effect (liever willen leren met een nieuwe technologie) komt vaker voor (zie bijvoorbeeld Sung \& Mayer, 2013), maar heeft ook een nadelige kant. Uit onderzoek blijkt namelijk vaak dat leerlingen willen leren met behulp van ict-toepassingen omdat ze dat gemakkelijker en minder belastend vinden, maar daardoor minder inzet vertonen en minder gaan presteren. De relatie tussen interesse en resultaat is in die gevallen dus negatief (Bernard et al., 2004). De openstaande vraag is of de hier gevonden verschillen in leerresultaten ook gevonden worden als leerlingen zich vaker op deze manier voorbereiden op een toets en of er een effect op de langere termijn is.

In ons onderzoek hebben we de tijd om te lezen gelijk gehouden aan de tijd om de video's te bekijken, en deze tijd was voldoende om de tekst te lezen. Het is echter mogelijk dat er meer tijd nodig is om een tekst studerend te lezen, dat wil zeggen met (meerdere keren) teruglezen van passages. Als er te weinig tijd is geweest is om goed studerend te lezen, dan verklaart dit mogelijk ook een deel van het effect. Het is aan de andere kant natuurlijk positief te noemen dat met een half uur voorbereiden met video's, leerlingen deze resultaten behalen. Wanneer leerlingen normaal gesproken meer tijd zouden besteden aan het lezen van het boek, zou er, als ze dit vervangen door bekijken van video's, tijd vrijkomen voor andere zaken.

Het onderzoek is gedaan binnen het vak natuurkunde. De concepten uit dit vak zijn mogelijk extra gebaat bij uitleg met bewegende beelden en animaties, zoals in de door ons geselecteerde filmpjes. Of het effect voor andere, niet-exacte vakken ook bestaat, zou in een vervolgonderzoek bekeken moeten worden. Het is in elk geval niet zo dat alleen de docenten uit de exacte vakken gebruik maken van video's of YouTube.

Een laatste kanttekening is dat de filmpjes die de leerlingen te zien kregen door ons zelf zijn gekozen. Dit heeft als voordeel dat de kwaliteit ervan in elk geval gecontroleerd is en zij naar ons oordeel een goede afspiegeling van het boek en van de inhoud van de les zijn. Interessant zou zijn om te kijken wat er gebeurt als leerlingen zelf filmpjes mogen kiezen om de toets voor te bereiden. Waar letten ze dan op? Is het effect kleiner als ze zelf filmpjes zoeken?

Deze studie levert sterke aanwijzingen dat de onderwijspraktijk baat heeft bij de uitbreiding van het lesaanbod met (centraal georganiseerde) instructiefilmpjes voor de verwerving van kennis. Hoewel er nog vervolgonderzoeken nodig zijn, kan voorzichtig geconcludeerd worden dat docenten die filmpjes maken (of door collega's gemaakte filmpjes aan hun leer- 
lingen aanraden) waarin de stof van het boek kernachtig wordt uitgelegd, hun leerlingen een goede dienst bewijzen.

\section{Appendix}

Tabel A De invloed van klas, volgorde op de hoogte van de verschilscores (in percentielen), lineaire regressie-analyse $(n=58)$

\begin{tabular}{l|r|r|r|r|c}
\hline Variabelen & B & $\begin{array}{c}\text { Standaard- } \\
\text { fout }\end{array}$ & Beta & t-waarde & p-waarde \\
\hline Intercept & 23,91 & 7,61 & & 3,14 & 0,01 \\
\hline Volgorde boek lezen - video & $-5,26$ & 8,06 & $-0,09$ & $-0,65$ & 0,51 \\
\hline Welke klas zit leerling (5 of 6) & 5,46 & 8,14 & 0,09 & $-0,67$ & 0,51 \\
\hline
\end{tabular}

Tabel B De invloed van klas, volgorde en interactie klas/volgorde op de hoogte van de verschilscores (in percentielen), lineaire regressie-analyse $(n=58)$

\begin{tabular}{|l|r|r|r|r|r}
\hline Variabelen & B & $\begin{array}{c}\text { Standaard- } \\
\text { fout }\end{array}$ & Beta & t-waarde & p-waarde \\
\hline Intercept & 22,18 & 9,30 & & 2,38 & 0,02 \\
\hline Volgorde boek lezen - video & $-2,18$ & 12,43 & $-0,04$ & $-0,18$ & 0,86 \\
\hline Welke klas zit leerling (5 of 6) & 8,30 & 11,94 & 0,14 & 0,70 & 0,49 \\
\hline Interactie tussen volgorde en klas & $-5,38$ & 16,43 & $-0,08$ & $-0,33$ & 0,75 \\
\hline
\end{tabular}

\section{Noten}

1. De toetsen zijn te vinden op onze website: http://www.ru.nl/sociologie/mt/boekbeeld/ home/.

2. In dit artikel zijn de betrouwbaarheidsintervallen en significanties bepaald door per groep 1 miljoen onafhankelijke steekproeven met teruglegging te gebruiken. Vervolgens zijn in elk van deze bootstrap-steekproeven de percentielscores voor toets 1 en toets 2 berekend voor de leerlingen uit klas 5 en voor de leerlingen klas 6. Daarna is het gemiddelde aantal goede antwoorden en de gemiddelde percentielscore berekend per groep. Tot slot zijn per groep de 5 procent meest extreme gemiddelden bepaald in de linkerhelft en in de rechterhelft van de steekproevenverdeling van beide toetsen. Voor details zie: http://www.ru.nl/sociologie/mt/boekbeeld/home/.

3. De percentielscore is hier gedefinieerd als het percentage leerlingen met een cijfer gelijk of lager dan het cijfer van leerling x. Stel, er zijn 10 leerlingen met respectievelijk de cijfers $5,5,5,6,7,8,8,8$, 9 en 1o. De leerling met het oorspronkelijke cijfer 6 heeft dus de percentielscore 40: 4 van de 10 leerlingen ( $=40$ procent) hebben een cijfer 6 of lager. De volledige reeks met percentielscores is $30,30,30,40,50,80,80,80$, 90, 100. Als de laatste 4 cijfers gehaald zijn met het kijken naar video's, dan is de gemiddelde percentielscore 
$87,5(80+80+90+100) / 4$. Dit resultaat is te vergelijken met de gemiddelde percentielscore die deze vier leerlingen scoorden op de toets die zij hebben voorbereid met het lezen van het boek. In ons onderzoek bleek dat gemiddelde steeds lager te liggen, met andere woorden: het kijken naar video's levert een relatief beter resultaat op dan de boekvoorbereiding.

4. De analyses in tabel 2 zijn ook uitgevoerd met z-scores, waarbij het relatieve verschil wordt uitgedrukt in standaardafwijkingen in plaats van percentielscores. Dit leverde een identiek beeld op. Voor details zie http://www.ru.nl/sociologie/mt/boekbeeld/ home/.

\section{Referenties}

Bergmann, J., \& Sams, A. (2009). Remixing Chemistry Class: Two Colorado Teachers Make Vodcasts of Their Lectures to Free Up Class Time for Hands-On Activities. Learning and leading with technology, 39, 22-27.

Bernard, R. M,, Abrami, P. C., Lou, Y., Borokhovski, E., Wade, A., Wozney, L., Wallet, P. A., Fiset, M., \& Huang, B. (2004). How does distance education compare to classroom instruction? A meta-analysis of the empirical literature. Review of Educational Research, 73, 379-439.

Boster, F. J., Meyer, G. S., Roberto, A. J., Inge, C., \& Strom, R. E. (2006). Some effects of video streaming on educational achievement. Communication Education, 55, 46-62.

Crippen, K. J., \& Earl, B. L. (2004). Considering the efficacy of web-based worked examples in introductory chemistry. Journal of Computers in Mathematics and Science Teaching, 23, 151167.

Dupagne, M., Millette, D. M., \& Grinfeder, K. (2009). Effectiveness of video podcast use as a revision tool. Journalism \& Mass Communication Educator, 64, 54-70.

Fox, J. (2002) An R and S-PLUS Companion to Applied Regression. Los Angeles: Sage.

Ginns, P. (2005). Meta-analysis of the modality effect. Learning \& Instruction, 15, 313-331.

Gog, T. van, Verveer, I. \& Verveer, L. (2014). Learning from video modeling examples: Effects of seeing the human model's face. Computers \& Education, 72, 323-327.

Harskamp, E. G., Mayer, R. E., \& Suhre, C. (2007). Does the Modality Principle for Multimedia Learning Apply to Science Classrooms? Learning and Instruction, 17, 465-477.

Jensen, J. L., Kummer, T. A., \& Godoy, P. D. d. M. (2015). Improvements from a Flipped Classroom May Simply Be the Fruits of Active Learning. CBE - Life Sciences Education, 14, 1-12.

Kay, R. H. (2012). Exploring the use of video podcasts in education: A comprehensive review of the literature. Computers in Human Behavior, 28, 820-831.

Kennisnet (2015). Monitor Jeugd en Media 2015. Kennisnet.

Marks. H. (2000). Student engagement in instructional activity: Patterns in the elementary, middle and high school years. American Educational Research Journal, 37, 153-184.

Mayer, R.E. (2009). Multimedia learning (2de ed.), Cambridge: University Press.

McLaughlin, J. E., Roth, M., Glatt, D. M., Gharkholonarehe, N., Davidson, C. A., Griffin, L. M., Esserman, D. A., \& Mumper, R. J. (2014). The flipped classroom: a course redesign to foster learning and engagement in a health professions school. Acad Med, 89, 1-8.

Renshaw, C. E., \& Taylor, H. A. (2000). The educational effectiveness of computer-based instruction. Computers and Geosciences, 26, 677-682.

Sung, E., \& Mayer, R. E. (2013). Online multimedia learning with mobile devices and desktop 
computers: An experimental test of Clark's methods-not-media hypothesis. Computers in Human Behavior, 29, 639-647.

Traphagan, T., Kusera, J. V., \& Kishi, K. (2010). Impact of class lecture webcasting on attendance and learning. Educational Technology Research and Development, 58, $19-37$.

Van Eekelen, G. \& Jong, de R (2007). Systematische Natuurkunde / 5 vwo. Amersfoort: ThiemeMeulenhoff.

Van Eekelen, G. \& Jong, de R (2009). Systematische Natuurkunde / 6 vwo. Amersfoort: ThiemeMeulenhoff.

Warter-Perez, N., \& Dong, J. (2012). Flipping the Classroom: How to Embed Inquiry and Design Projects into a Digital Engineering Lecture. Proceedings of the 2012 ASEE PSW Section Conference.

\section{Over de auteurs}

Manfred te Grotenhuis is universitair docent kwantitatieve analysetechnieken bij de sectie Sociologie van de Radboud Universiteit Nijmegen. Zijn onderzoeksbelangstelling gaat uit naar toepassingen van regressieanalyse, meerniveau-analyse en tegenfeitelijkheidsanalyse. Postadres: Sectie Sociologie, Radboud Universiteit, Postbus 9104, 6500 HE Nijmegen.

E-mail: m.tegrotenhuis@maw.ru.nl

Amber Walraven is universitair docent aan de Radboud Docenten Academie van de Radboud Universiteit Nijmegen. Haar onderzoek richt zich met name op het (samen met docenten) ontwerpen van ICT-rijke leeromgevingen en het meten van het effect daarvan. Ze is geïnteresseerd in zowel leerlingen als docenten en in de vraag hoe zij het meeste uit leren en onderwijs kunnen halen. Postadres: Radboud Docenten Academie, Radboud Universiteit Postbus 9103, 6500 HD Nijmegen

E-mail: a.walraven@docentenacademie.ru.nl

Nico van de Mortel is een ict-student op de Fontys Hogeschool te Eindhoven. Tijdens zijn afstuderen aan het Willibrord Gymnasium te Deurne onderzocht hij in het kader van zijn profielwerkstuk de invloed van YouTube-filmpjes ter voorbereiding op een toets. Deze gegevens leverde hij aan voor verder onderzoek. Postadres: Sint Jozefstraat 15, 5753AR te Deurne. E-mail: nicovdmortel@hotmail.com 